\title{
Factors That Affect The Event Of Hipertension In Elderly In The Herlang Puskesmas
}

Working Area

\author{
Endang1, Safruddin'2,Muriyati ${ }^{3}$ \\ S1 Nursing Study Program, Stikes Panrita Husada Bulukumba, Indonesia ${ }^{1}$ \\ Departemen Community and Family Nursing , Stikes Panrita Husada Bulukumba, Indonesia ${ }^{2}$ \\ Departemen Medical Surgical Nursing, Stikes Panrita Husada Bulukumba ,Indonesia ${ }^{3}$
}

Corresponding Autor : endangsriernawati40@gmail.com

\begin{abstract}
According to data from the 2014 Bulukumba health service, there were 6,355 people with hypertension and in 2016 there were 10,430 people and there were 11,714 blood pressure measurements, this hypertension increased every year. The purpose of this study is to know the factors that influence the incidence of hypertension in the elderly. Research design with 'Crosssectional' 'the population in this study were elderly in the working area of the Herlang Public Health Center many as 120 respondents, the sample in this study amounted to 62 respondents take by using a Multivariate formula, data analysis using the result of this study indicates using the chi-square test with the value $(p=0.027)$, which men that there is an effect of smoking on the incidence of hypertension. And the consumption of salt with values $(p=0.012)$, which means there is an influence of salt consumption on the incidence of hypertension and lack of physical activity obtained values $(p=0.012)$ which means there is an influence on the incidence of hypertension in the elderly. The conclusion of this research is' there is an influence between smoking, consuming salts and lack of physical activity in the working area of the Herlang Public Health Center. It is suggested that the results of this study can be used as scientific reading material in the library and can also be used as reference material for students who examine the problem.
\end{abstract}

\section{Keywords : Lifestyle, Hypertension, Elderly}

\section{INTRODUCTION}

Hypertension is a condition when systolic blood pressure is more than $120 \mathrm{mmHg}$ and diastolic pressure is more than $80 \mathrm{mmHg}$. Hypertension often causes changes in blood vessels resulting in higher blood pressure can cause complications in several organs of the body such as the heart, kidneys, and brain. Epidemiological investigations require that high blood pressure is closely related to cardiovascular morbidity and morbidity and conditions that are often found in primary care (Muttaaqin, 2009).

According to the World Health Organization (WHO 2015), the incidence of hypertension is almost 1 billion people worldwide have high blood pressure. Hypertension is one of the leading causes of premature death worldwide. In 2020 about 
1.56 billion adults will live with hypertension, hypertension kills nearly 8 billion people every year in the world and nearly 1.5 million people each year in the east-south Asia region. About one-third of adults in east-south Asia and the sequence include Indonesia who suffers from hypertension (Bulukumba district health profile, 2011). The results of the 2014 Basic Health Research (Riskesdes) by the RI Ministry of Health's research and development body, showed a national hypertension prevalence of 31.7\% (Risekedes, 2014). Factors that influence hypertension into two groups namely inherent or irreversible factors such as genetic, age, sex, race, and factors that can be changed such as diet, physical activity, and others. For the occurrence of hypertension, these factors need to play a role together, in other words, one factor alone is not enough to cause hypertension (Hakim, Ali, \& Tyekyan, 2015).

Based on the results of data obtained from the Herlang Community Health Center each year, there has also been an increase, such as from the data obtained from 2015 the number of clients suffering from hypertension was 90 people, in 2016 as 100, in 2017 as many as 120. Based on the results of previous studies conducted by (Setyaningsih, Dewi, \& Suandik, 2014), based on epidemiology revealed that fenemona which showed that the consumption of salted food was a risk factor for hypertension and from the results of research conducted by (Putri, 2014), shows that lack of activity and smoking can cause hypertension.

The impact if blood pressure increases can cause sepesif organ damage, if hypertension occurs prolonged it will increase the risk or the impact of diseases such as stroke, heart attack, heart failure and diabetes mellitus. If people with severe hypertension can experience encephalopathy, which is a decrease in awareness and even coma. The purpose of this study is to determine whether there is an influence between smoking, consuming salt and lack of physical activity with the incidence of hypertension in the elderly in the Work Area of Herlang Puskesmas, Herlang District, Bulukumba Regency.

\section{MATERIAL AND METHOD}

The research design used in this study is the Cross-Sectional research design (Darhma, 2011). The aim is to determine the effect of smoking, salt consumption, and lack of physical activity with the incidence of hypertension in the elderly in the Work Area of Herlang Puskesmas, Herlang District, Bulukumba Regency. Population is a generalization area that consists of objects/subjects that have certain qualities and 
characteristics determined by researchers to be studied and then drawn conclusions (Saryono, 2010). The population in this study is the elderly who suffer from hypertension and do not suffer from hypertension with a population of 120 people.

Sampling uses a purposive sampling technique in which the sampling method is based on a particular consideration made by the researcher himself, based on or characteristics of the population that has been known previously. (Notoatmodjo, 2012). The number of samples in this study were 62 elderly. The instruments used in this study consisted of 3 types, namely using observation sheets, questionnaires, and interviews, observation sheets were used to determine the blood pressure of respondents using a blood pressure meter and a stethoscope. The interview is used to find out whether the respondent smokes. While the questionnaire was used to collect data about salt consumption and lack of physical activity. The research instrument (questionnaire) must meet the requirements of valid and reliable with a value of $r$ (corrected item-total correlation) 0.514 .

Data were analyzed based on measuring scale and research objectives using computerized program software. Data were analyzed by: (1). Univariate Analysis is an analysis conducted to analyze variables. (2). Bivariate Analysis, Bivariate Test is an analysis carried out by more than two variables. The statistical test used is the Chisquare test if it meets the requirements but if it does not meet the fisher test requirements. This test aims to see whether there is a significant difference in proportion between the frequency distribution which is expected to be expected with a significance level of 0.05 . If $\mathrm{p}$-value $<0.05$ means there is a significant influence (Ho is rejected) while $\mathrm{p}$-Value $>0.05$ means there is no significant effect (Ho is accepted).

\section{RESULT}

Table 1 Distribution of Respondent Characteristics in the Work Area of Herlang Health Center

\begin{tabular}{llc}
\hline \multicolumn{1}{c}{ Characteristic } & n & Percentage (\%) \\
\hline Gender & 31 & 50,0 \\
Male & 31 & 50,0 \\
Female & & \\
Age & 56 & 90.3 \\
Elderly & 5 & 8.1 \\
Elderly & 1 & 1,6 \\
Old Age & & \\
Level Of Education & 2 & 3.2 \\
No school & 54 & 87.1 \\
SD & 4 & 4.8 \\
SMP & &
\end{tabular}




$$
\text { SMA }
$$

Profession

Not Working

Working

Fhiserman
3

18

28

16
4.8

29.0

45.3

25.8

Based on (Table 1) shows that in the Work Area of Herlang Health Center, most of the age of respondents are in the elderly category with 56 respondents or around (90.3\%), most respondents are male and female 31 people (50.0), respondents with an elementary school education of 54 people (87.1\%), based on the most work, namely respondents who worked as many as 28 people around (45.3\%).

Table 2. Frequency distribution of the number of respondents

\begin{tabular}{|c|c|c|}
\hline Varible & $\mathbf{N}$ & Percentaeg (\%) \\
\hline \multicolumn{3}{|l|}{ Smoke } \\
\hline Don't Smoke & 29 & 46,8 \\
\hline Smoke & 33 & 53,2 \\
\hline \multicolumn{3}{|l|}{ Salt Consumption } \\
\hline High & 38 & 61,3 \\
\hline Normal & 24 & 38,7 \\
\hline \multicolumn{3}{|l|}{ Physical Activity } \\
\hline Activity & 38 & 61,3 \\
\hline Don't Aktivity & 24 & 38,7 \\
\hline \multicolumn{3}{|l|}{ Hypertension } \\
\hline Don't Hypertension & 38 & 61,3 \\
\hline Hypertension & 24 & 38,7 \\
\hline Amount & 62 & 100 \\
\hline
\end{tabular}

Based on Table 2 shows as many as in the Working Area of Herlang Health Center respondents who have smoking behavior as many as 29 people (46.8\%), smaller compared with those who have smoking behavior as many as 33 people (53.2\%). shows that in the Working Area of Herlang Puskesmas the respondents who consumed the most salt were 38 people (61.3\%) in the high category, compared to 24 in the normal category (37.5\%). shows that in the Work Area of Herlang Public Health Center, 38 respondents (61.3\%) lack physical activity, compared to 24 (38.7\%) of physical activity. Shows in the Work Area of Herlang Health Center respondents who suffered hypertension as many as 38 (61.3\%), compared with those who did not suffer from hypertension as many as $24(38.7 \%)$. 
Table 3. Effects of smoking, salt consumption and lack of physical activity with the incidence of hypertension in the elderly

\begin{tabular}{|c|c|c|c|c|c|c|}
\hline \multirow{3}{*}{ Smoke } & \multicolumn{4}{|c|}{ Hypertension } & \multirow{3}{*}{ Amount } & \multirow{3}{*}{$P$} \\
\hline & \multicolumn{2}{|c|}{ Hypertension } & \multicolumn{2}{|c|}{ Don't Hypertension } & & \\
\hline & $\mathbf{N}$ & $\%$ & $\mathrm{n}$ & $\%$ & & \\
\hline Smoke & 22 & 59,0 & 7 & 29,0 & 38 & \multirow{2}{*}{0,027} \\
\hline Don't Smoke & 16 & 48,5 & 17 & 51,5 & 24 & \\
\hline \multirow{2}{*}{$\begin{array}{l}\text { Consumption } \\
\text { Salt }\end{array}$} & & & & & \multirow[t]{2}{*}{ Amount } & \multirow[t]{2}{*}{$P$} \\
\hline & $\mathbf{N}$ & $\%$ & $\mathbf{n}$ & $\%$ & & \\
\hline High & 28 & 73,7 & 10 & 16,1 & 38 & \multirow{2}{*}{0,012} \\
\hline Normal & 10 & 16,1 & 14 & 22,6 & 24 & \\
\hline \multirow[t]{2}{*}{ Physical Activity } & & & & & \multirow[t]{2}{*}{ Amount } & \multirow[t]{2}{*}{$P$} \\
\hline & $\mathrm{N}$ & $\%$ & $\mathbf{n}$ & $\%$ & & \\
\hline Heavy & 28 & 73.7 & 10 & 16.1 & 38 & \multirow{3}{*}{0,012} \\
\hline Light & 10 & 16,1 & 14 & 22,6 & 24 & \\
\hline Amount & 38 & 100 & 24 & 100 & 62 & \\
\hline
\end{tabular}

Based on table 3, it shows in the Work Area of Herlang Health Center that respondents show the effect of smoking with the incidence of hypertension in the elderly where respondents who behave smoke as much as 29 (46.8\%), smoking who suffer from hypertension as much as 22 (59.0\%), compared with smoking did not suffer hypertension as much as 7 (29.0\%), did not smoke and did not suffer hypertension as much as 17 (51.5\%), so that as a percentage it can be concluded that there is an effect of smoking with the incidence of hypertension in the elderly. Chi-square test results obtained a value of $\mathrm{p}=0.027(\mathrm{p}<0.05)$, it was concluded that there is a significant effect between smoking and the incidence of hypertension in the elderly.

Based on the table Shows in the Work Area of Herlang Health Center respondents who consume salt with the incidence of hypertension in the elderly where respondents consume 38 salt (61.3\%), consume high category of salt who suffer from hypertension as much as 28 (73.7) compared to consuming high salt which did not suffer from hypertension as much as 10 (16.1\%), consumed normal salt as many as 24 respondents (38.7\%) consumed normal salt who suffered hypertension as much as 10 (16.1\%), compared with those who consumed Normal salt who did not suffer from hypertension as much $14(22.6 \%)$. So as a percentage it can be concluded that there is an effect of consuming salt with the incidence of hypertension in the elderly. Chi-square test results 
obtained a value of $\mathrm{p}=0.012(\mathrm{p}<0.05)$, then it is concluded that there is a significant effect between consuming salt with the incidence of hypertension in the elderly.

Based on the table Shows in the Working Area of Herlang Health Center respondents who consumed salt with the incidence of hypertension in the elderly where respondents who lack physical activity as many as 38 respondents (61.3\%), less physical activity who suffer from hypertension 28 (45.2\%), compared with lack of physical activity suffering from hypertension as much as 10 (16.1\%), respondents who are active as much as 24 respondents (38.7\%), activity who suffer from hypertension as much as 10 (16.2\%), compared with those who do and are not hypertensive as much as 14 (22.6\%). So as a percentage it can be concluded that there is a lack of physical activity with the incidence of hypertension in the elderly. Chi-square test results obtained $\mathrm{p}$ value $=0.012(\mathrm{p}<0.05)$, it concluded that there was a significant influence between lack of physical activity with the incidence of hypertension in the elderly.

\section{DISCUSSION}

In this study shows that there is a significant influence between smoking, salt consumption and lack of physical activity with the incidence of hypertension in the elderly in the Work Area of Herlang Health Center, Herlang District, Bulukumba Regency. Based on statistical results performed using the chi-square test, the value of $p$ $=0.027$ is smaller than $\mathrm{a}=0.05$. So Ho was rejected and Ha was accepted. This proves that smoking influences the incidence of hypertension in the Work Area of Herlang Health Center. This is in line with Hengli's study (2013). Explain that someone with smoking behavior has a risk of 2.32 times suffering from hypertension compared to nonsmokers with a value of $\mathrm{p}=0.003$.

Researchers argue that smoking behavior is one of the factors that support the incidence of hypertension because the average person consumes cigarettes. This is mainly caused by nicotine which can stimulate the sympathetic nerves so that it triggers the work of the heart harder and causes constriction of blood vessels. The longer a person smokes a cigarette, it will have a major effect on rising blood pressure or hypertension. Based on statistical results performed using the chi-square test, the value of $\mathrm{p}=0.012$ is smaller than $\mathrm{a}=0.05$. Then Ho was rejected and Ha was accepted. This proves that consuming salt has an effect on the incidence of hypertension in the Work Area of Herlang Puskesmas. plays an important role in the emergence of hypertension. 
What is meant by salt here is sodium salt, both in the form of table salt added during cooking and all food ingredients that contain high sodium, with a value of $\mathrm{p}=$ 0.020. Researchers believe that consuming more salt is less good and very triggers hypertension than those who do not consume salt which is not too excessive because many people consume processed foods such as salted fish or dried fish because people do not know the content contained in salt and do not know one of the triggers for an increase in blood pressure. Based on statistical results performed using the chi-square test, the value of $\mathrm{p}=0.012$ is smaller than $\mathrm{a}=0.05$. Then Ho was rejected and Ha was accepted. This proves that lack of physical activity influences the incidence of hypertension in the Work Area of Herlang Health Center. This is in line with research Wiwi Sartika (2014) said that people not doing less physical activity can increase the risk of blood pressure and a person those who are not physically active have a 30-50\% greater risk of developing hypertension, with a $\mathrm{p}$ value $=0.001$.

Researchers are of the opinion that, physically there are still many elderly people who do less physical activity due to various factors such as health factors, age factors and employment factors, lack of activity is very influential on hypertension, if the respondent lacks physical activity then the blood circulation is less smooth so that it can cause blockage of blood vessels.

\section{CONCLUSION}

Based on the above research results, it is concluded that there is a significant influence between smoking, salt consumption and the incidence of hypertension in the elderly in the Work Area of Herlang Health Center, Heram Kecamatang, Bulukumba Regency in 2018. The results of the research hopefully can be used as material to increase insight in the field of research and increase knowledge about the factors that influence the incidence of hypertension in the elderly in the Work Area of Herlang Health Center, Herlang District, Bulukumba Regency in 2018 and the Puskesmas / related institutions need to follow up in order to prevent the triggering factors for the occurrence of hypertension and subsequent researchers in order to conduct research with an epidemiological study design stronger, that is by case control or cohort so that the magnitude of the risk of each variable can be measured more clearly. 


\section{REFERENCES}

Agustina, S., Sari, S. M., \& Savita, R. (2014). Faktor-faktor yang berhubungan dengan kejadian hipertensia pada lansia di atas unur 65 tahun.

Alberta, L. T., proboningsih, J., \& Almahmuda, M. (2014). peningkatan perilaku diet rendah garam berbasis pada lansia penderita hipertensi. jurnal ners.

Azizah, M. L. (2011). keperawatan Lanjut Usia. yogyakarta: Graha ilmu.

Darhma, k. k. (2011). metodologi penelitian keperawatan.

Djauhar, A., Dewi, H., \& Rusnoto. (2013). Faktor-faktor yang berhubungan dengan kejadian hipertensi pada lansia Di Pusling Desa kLumpit UPT puskesmas Gribig kabupaten kudus.

Hakim, A., Ali, Z., \& Tyekyan, S. (2015). Prevelensi dan Faktor-faktor hipertensi di kecamatan Llir timur II Palembang. Mks.

Joyce M, B., \& Hokanson, J. H. (2014). keperawatan medikal bedah. singapura: Elsevier.

Junaedi, E. (2013). Hipertensi kandas Berkat Herbal. jakarta selatan: Fmedia.

Muttaqin, A. (2009). Asuhan keperawatan klien dengan gangguan sistem kardiovasuler. jakarta : salemba medika.

Notoatmodjo, s. (2012). Metodologi Penelitian kesehatan . Jakrta: Rineka cipta.

Nursalam. (2008). Edisi 2. Konsep dan penerapan metodologi penelitian ilmu keperawatan pedoman skripsi, tesis, dan instrument penelitian keperawatan. Jakarta: Salemba medika.

Prasetyaningrum, I. Y. (2014). Hipertensi bukan untuk Ditakuti. jakarta: Fmedia(Imprint Agromedia pustaka).

Putri, p. L. (2014). Gambaran prevelensi dan faktor resiko hipertensi pada penduduk usia produktif Di desa rendang, kecamatan rendang,kabupaten karAngasem.

Rahajeng, E., \& Tuminah, S. (2009). prevelensi hipertensi dan determinannya di indonesia. Artikel penelitian.

Riyadi, S. (2014). Keperawatan Medikal Bedah. Yogyakarta: Pustaka Pelajar.

Saryono. (2011). metodologi penelitian kesehatan.

Setiawan, a. s. (2010). metodologi penelitian kebidanan.

Setyaningsih, R. D., Dewi, P., \& Suandik, M. (2014). Studi prevelensi dan kajian faktor risiko hipertensi lansia Di desa Tambaksari-Banyumas.

Siringoringo, M., Hiswani, \& Jemadi. (2013). Faktor-faktor yang berhubungan dengan hipertensi pada lansia di desa sigaol simbolon kabupaten samosir.

Suprapto, I. H. (2014). Menu Ampuh Atasi Hipertensi. yogyakarta: Notebook. 
Yusuf, S. F. (2015). Metodelogi penelitian kesehatan. Jl.Belibis No.1 perumuhan Sopo Indah siguling ke.padangsidimpuan Utara: Darmis Press-padangsidimpuan.

Wahyuningsih, \& Astuti, E. (2013). Faktor yang mempengaruhi hipertensi pada usia lanjut. Journal Ners And Midwifery Indonesia.

WHO. (2013).

Yossi, F. (2014). Faktor-faktor yang berhubungan dengan kejadian hipertensi pada usia lanjut Di wilayah kerja puskesmas kebun sikolos kecamatan padang panjang barat.

A. D., Rusnoto, \& H. D. (2013). Faktor-faktor yang berhubungan dengan kejadian hipertensi pada lansia Di Pusling Desa Klumpit UPT Puskesmas Gribilng kabupaten Kudus.

A. E. (2013). Faktor-faktor yang mempengaruhi hipertensi pada usia lanjut Di Dusun Kabregan, Srimulya, piyungan, Bantul Yogyakarta.

A. P., \& Novi. (2013). Hubungan pola konsumsi natrium dan kalium serta aktvitas fisik dengan kejadian hipertensi pada pasien rawat jalan Di RSUD Dr Wahidin Sudirohusodo makassar.

M. M., Anida, \& yuli. (2012). Hubungan aktvitas fisik dengan tekanan darah pada lasia Di Dusun Miri Desa Srihaja Imagiri Bantul yogyakrta.

S. W. (2014). terkontrolnya tekanan darah berdasarkan aktvitas fisik .

Susanti. (t.thn.). Hubungan asupan natrium dengan tekanan darah pada lansia dikelurahan padang .

Susanti, R. M. (2014). Hubungan asupan natrium Dengan tekanan darah pada lansia Di Kelurahan Paang .

Situmorang, P. R. (2015). Faktor-faktor Yang Berhubungan Dengan Kejadian Hipertensi Pada Penderita Rawat Inap di Rumah Sakit Umum Sari Mutiara Medan. Jurnal Ilmiah Keperawatan.

Yashinta, o. g., Delmi, s., \& yuniar lestari. (2015). Hubungan merokok dengan kejadian hipertensi laki usia 35-65 tahun dikota padang . kesehatan Andalas. 